\title{
SPEECH CULTURE IN PROFESSIONAL COMMUNICATION
}

\section{Yermolenko S. Ya.}

\section{INTRODUCTION}

The state status of the Ukrainian language raised the issue of the enlargement of its communicative and cognitive functions as an important factor in state formation, a reliable mechanism of consolidating society. New public conditions for the functioning of the Ukrainian language motivate, first, comprehension of such a concept as national-linguistic consciousness associated with self-awareness, self-determination of the nation, the discovery of its identity culture. Secondly, they raise the questions of the indepth study of the Ukrainian language as a literary language standard, which is an important, historically determined variety of the national language in its dynamics, given the conditions of globalization, significant migration processes and the influence of unlimited information space.

The concepts of "state language", "national language", "literary language" in relation to the Ukrainian language provide the appropriate content in context of the history of terminology of these concepts. If the first is explicated in legal, legislative documents, the second needs further linguistic definition due to the fact that it is often used in the humanities discourses, without distinguishing between such varieties of the national language as literary language and the language of territorial and social dialects.

In the historical and cultural discourse of the XIX century there was a formation of the concept of the Ukrainian language as an active subject in the history of the Ukrainian people, who, in conditions of statelessness, fought for the right to have their own language not only for domestic use, but also to develop education, culture and enter the civilized world as an authentic Slavic nation.

Divided between different states, the stateless Ukrainian nation has walked the difficult path of formation of the literary variety of the national language, that language standard, which in modern conditions is an important factor in consolidating society, as well as an instrument of professional communication in various fields of human activities.

Literary language is a phenomenon of communication, codified and developed in all areas of science, education, culture and production. It provides real multifunctionality, social prestige of the language that unites society and ensures the integrity of the national culture. 


\section{The history of the concept of literary language}

The specific meaning of the term "literary language" is being rethought in certain historical periods of development of the national culture. L.A. Bulakhovskyi emphasized such characteristic features of literary language as its written character, unifying (integration) tendencies and normativeness. The researcher noted that the normativeness of oral spoken language is formed under the influence of the written one, "but the very standard, strict normativeness of written language are mostly a phenomenon of later times"1. The following signs of literary language are constant: literary norm; interaction of literary language with territorial and social dialects; preservation of previous traditions in literary language; the ratio of literary language and the language of fiction; impact of speaking practice on literary language and social dialects.

The concept of normalized literary language is formed in societies with appropriate level of education, science and culture development. Literary language in its own relevant feature - the presence of an established norm (phonetic, lexical, word building, morphological, syntactic) - strives for standardization, uniformity, preservation of traditions.

Rationing and codification are two processes that are reflected in grammars, dictionaries. They record the literary norm as usage examples of language in formal, scientific, educational and informational areas. Exemplary literary language requires a long formation and establishment. It also certifies a certain level of education in society, as well as the execution of integrative and unifying functions by the national language.

For Ukrainians, the question of the unity of the nation and a single literary language has acutely arisen in the second half of the XIX century, as well as in the early XX century due to the existence of variants (written and literary practices) of the Ukrainian literary language ${ }^{2}$.

Ivan Franko saw the basis of a single literary model in a certain type of language, "which in a huge area from Kharkiv to Kamianets-Podilsky showed such homogeneity, such a lack of sharper differences, which fully corresponded to the Ukrainian national type, also "mixed" and aligned as a whole mass, as few others in the world do. Everyone, Galician or Ukrainian, who wants to speak in print to the largest mass of Ukrainian people, must use the language of the largest mass, the language produced by the largest number of talented and popular writers"3. The writer could not stand aside

${ }^{1}$ Булаховський Л.А. Виникнення літературних мов. Вибрані праці в 5-ти томах. Т. 1. Київ : Наукова думка, 1975. С. 323.

${ }^{2}$ Матвіяс I. Варіанти української літературної мови. Київ, 1998. С. 124-150.

${ }^{3}$ Франко І. Зібрання творів у 50-ти томах. Т. 37. Київ, 1982. С. 206. 
from the linguistic discussions that erupted in the late XIX century and early $\mathrm{XX}$ century. Making efforts to form an all-Ukrainian literary language, I. Ya. Franko "found in the linguistic and literary dispute a democratic, broad approach, the foresight that was ultimately intended to achieve unification, to bring together the nascent in the linguistic practice of different regions, and thus bring together the alternative rules, if not overcome, then at least minimize cultural and ethnic differences"

Exploring the role of playwrights of the late XIX century and early XX century in the development of the Ukrainian literary language, Ya.V. Janusz characterizes, in particular, translations made by M. Starytskyi ${ }^{5}$. The researcher gives conceptual provisions of the playwright about the then state of the Ukrainian literary language: "Although I had at my disposal a language with an extremely rich vocabulary, able to convey a storm of passions and a tender song of love, but still it was the language of the vast fields and meadows, not of the royal chambers, foreign to the language eloquence of court etiquette, alien to the artificial subtlety of metaphors and others rhetorical ornaments" ${ }^{\prime \prime}$. Mykhailo Starytskyi devoted his talent as a writer and translator to the development of literary language. In a letter to Ivan Franko, he wrote: "From the first steps of self-knowledge in the field of the nation, I was ignited to serve my native word with my very soul and thought, to polish it, to give it beauty and strength, to make it able to express a cultural educated thing, to sing the finest beauties of high poetry... I wanted... to bring our word to the rank of a general ... " 7 .

In the second half of the XIX century, the question of the influence of the specific dialects on the Ukrainian literary language was topical. Lesya Ukrainka expressed her thoughts on the interaction of vernaculars and the formation of literary language in her letter to Osyp Makovei in such words: "... there is absolutely no sense in talking about the victory of one or the other dialect because literary language must be created from all dialects, with no violence, quarrels or fights" $"$.

\footnotetext{
${ }^{4}$ Кононенко В.І. Мова. Культура. Стиль: збірник статей. Київ-Івано-Франківськ, 2002. С. 410.

5 Януш Я.В. Українські драматурги-класики кінця XIX - початку XX ст. і українська мова. Життя у слові: зб. наук. праць на пошану академіка В.М. Русанівського. Київ, 2011. С. 432-433.

${ }^{6}$ Старицький М. Передмова до перекладу трагедії «Гамлет» В. Шекспіра. Твори у 8 т. Київ, 1963-1965. Т. 8: Оповідання ; Статті ; Листи. 1965. С. 356.

${ }^{7}$ Старицький М. Лист до І.Я. Франка. Початок червня 1902 р. Твори у 8 т. Київ, 1963-1965. Т. 8: Оповідання; Статті; Листи. 1965. С. 636.

${ }^{8}$ Українка Леся. Лист до А. С. Маковей від 28 січня 1894 р. Зібрання творів у 12 т. Київ, 1975-1979. Т. 10, 1978. С. 209-210.
} 
Exploring the modern communicative-stylistic complex of oral literary language, considering oral language as a system, S.P. Bybyk states: "The formation of the components of this system is a complex, long-lasting process due to the expansion from the household functions to the social ones" $"$.

In the context of liberalization of social relations, the growing role of types and genres of oral communication increases the number of alternative means of linguistic self-expression, but they are subject to the basic requirement - to be understandable to as many native speakers as possible, to identify appropriate level of education and language competence. Language education and modern media form the integral space in which the main, determining role belongs to the standardized literary language. Deviation from spelling or orthoepic norms, as well as attempts to introduce a new lexical, syntactic norm is still considered by the educated people as a lack of knowledge of modern literary language, as a violation of the codified language norms.

It is worth noting that reflections on the language norm has occurred before because the functioning of the norm is related to the category of evaluation, language habits and preferences of the person. Critical evaluation of the specific word usage, pronunciation, explanation of historical changes in language depend on actualization of the theory and history of literary language.

If in a broad sense, modern literary language is the language from the times of Ivan Kotliarevskyi to this day, which is actually confirmed by the dictionaries and educational philological literature, in the narrow sense the term "modern literary language" unites the communicative practice of three generations. This is a period of simultaneous life of older, middle and younger generations. The language of young people is always different from the language of older people, but it is balanced by the communicative activity of the middle generation, which determines the nature of the norms of modern literary language.

The relentless flow of the language river reflects constant changes in the life of society. In times of great social changes, socio-cultural landmark changes, the evolution of language is noticeable in much smaller time spans. Thus, we identify modern literary language with the language practice of the last $10-15$ years. Researchers of modern Slavic literary languages write about the changes in the evaluation of literary, exemplary, elite language. For example, referring to the controversial statement of a well-known researcher of Polish stylistic varieties of literary language Stanislav Haida on the "de-elitization of literary language", Stanislav Dubish reflects on the

${ }^{9}$ Бибик С.П. Комунікативний комплекс «усна мова»: сучасна проекція. Життя у слові: зб. наук. праць на пошану академіка В.М. Русанівського. Київ, 2011. С. 284. 
relationship between the terms literary and common Polish language at the turn of the XX and XXI centuries ${ }^{10}$.

Literary standard (as a standardized and codified in dictionaries and grammars polyfunctional and polythematic Ukrainian literary language) is formed in specific historical conditions. The concept of temporal and spatial depth of the literary norm ${ }^{11}$ makes it possible to connect the phenomenon of the new (and modern) literary language with the language of I.P. Kotliarevskyi, Taras Shevchenko, with the language consciousness of educated Ukrainians of the past centuries.

Functioning of literary language in written and oral forms, in different stylistic varieties determines the specifics of the implementation of the literary norm. Due to the dynamic stability of the literary norm, the connection between generations is ensured, the educational and cultural traditions of the nation are preserved.

\section{Spatial and temporal depth of the literary norm}

In the age of democratization of modern life, there is a change in regulatory stylistic consciousness of native speakers. There are different attitudes towards the literature norm: awareness of its necessity against modern processes of swaying norms; liberal attitude to innovations in the field of literary norm; chaotic use of language rules, which may be a deliberate violation of language norms as means of outrage, drawing attention to what is said, or an unconscious violation of the literary norm, i.e. ignorance of this norm. The chaos in language use is reflected in the language practice on the Internet, in particular in creation of both authentic and translated texts.

At the beginning of the XXI century, we observe differences, swaying in the graphic presentation of numerous English-originated loanwords. This vocabulary is in broad use in all areas of culture affected by globalization. The criteria for its rationing are contradictory because they are based on different principles: reproduction of the spelling or sound of a foreign word, written reproduction of the sound of individual sounds, which correspond to a certain letter in Ukrainian language. This traditional approach to spelling foreign words is applied in Ukrainian spelling standard. However, in modern language practice we observe violation of this tradition: the dynamics of integration of a foreign word is changing. In English loanwords the integral

\footnotetext{
${ }^{10}$ Dubisz Stanislaw. O tym, co sie stalo z jezykiem literackim - raz jeszcze. Stylistyka XXV. 2016. S. 133-143.

11 Літературна норма і мовна практика: монографія / Єрмоленко С.Я. Бибик С.П. Коць Т.А. та ін. ; за ред. Єрмоленко С.Я. Ніжин : ТОВ «Видавництво «АспектПоліграф», 2013 (320с.) С. 65-73.
} 
sound reproduction of words prevail over individual sounds. In addition, determining the source of foreign origin words, we cannot ignore the specific way in which the word comes into the modern Ukrainian language.

Those active processes that take place in the language of the media determine modern literary norm in its linguistic and oral functioning. The media increasingly influence the linguistic consciousness of native speakers of literary language. Mass character and ability to respond quickly to changes in modern vocabulary and language pragmatics make the language of modern media one of the main criteria of literary norm formation. Both written and oral forms of communication are represented in the media. This factor makes them all encompassing in the transformation of functional styles of literary language.

Considering linguistic consciousness in the paradigm of modern linguistics, emphasizing the ontological inseparability of the trinity "language - consciousness - culture", L.P. Hnatyuk makes an excursion into the history of domestic and foreign linguistics. Linguistic consciousness is a kind of reflection on language, varieties, forms, variants of its existence, on the literary norm itself. Since language consciousness exists in individual and social forms, we must emphasize that the literary norm reflects the social language consciousness and at the same time testifies to the stability and automatism of the norm in individual linguistic consciousness, as: "Linguistic consciousness is the essence of the language culture of an individual, social group, nation and society"12.

In the substantiation of normative word usage, they have always used the concept of "compliance with the language system". Such interpretation of the criterion of the norm establishment is objective, but it also undergoes subjective changes, when it comes to the fact that each native speaker defends language traditions which are close to him, especially the dialect environment in which his language competence was formed, his education and individual preferences acquired, etc.

In times of revision and reflection on the language norm, not only the increase of the number of possible variants can be assumed, but also diversifying of dictionaries of different communicative spheres. Due to the dynamics of literary norms, it is worth emphasizing the conceptual features of literary language, among which researchers distinguish the following: a) the degree of spatial consolidation of literary language; b) the age of the

12 Гнатюк Л.П. Мовна свідомість і мовна практика Григорія Сковороди в контексті староукраїнської книжноїтрадиції : Автореф. дис. ... д. філол. наук: 10.02.01 / Інститут філології Київського національного університету імені Тараса Шевченка. Київ, 2011. 35 с. 
literary language and the degree of its modernity; c) the influence of other languages in the process of contact with them; d) the spread of literary language outside its ethnic group; e) communicative rank of the language, i.e. the functions the language performs, its official status. This parameter is called the "vitality" of language, more precisely, viability; e) the degree of liberalism in national-language issues. The first two signs relate to the actual spatial and temporal depth of the literary norm. The language social prestige depends on the functioning of this norm, the social consciousness of people.

Socially prestigious language is the language used for writing and teaching. It is used for writing important state documents (laws), conducting court cases, informing society about the most important events in the state, the world. Depending on education, territorial origin of speakers, their professional, cultural level, social status, the assessment of literary language as socially prestigious form of the national language is formed in society.

Today we see an emphasis on the substandards of language - not only on dialectal sources of literary language, but also on vernacular, jargon. Negatively assessing the functioning of the literary language norm, the authors of such discussions do not want to notice that they use this norm as usual and convenient means of understanding. Literary language remains a socially prestigious form of the national language with its dynamically stable norm, which spatial and temporal depth is perceived differently depending on the educational level of its speakers.

Reiterating the idea that Eneyida is a treasure trove of spoken expressions of the Ukrainian language, we must note that not all of them are recorded in common vocabulary with appropriate stylistic remarks, some would deserve attention and introduction to modern vocabularies.

Can the word турбаиія be considered obsolete in the context of «Еней Анхизович, сідайте, Турбацію не заживайте?» The word мудраиія of the same stylistic color is marked as ironic, humorous in an 11-volume dictionary of the Ukrainian language. The vocabulary of synonyms by $\mathrm{S}$. Karavanskyi ${ }^{13}$ marks the word турбація as one "from the live language". Thus, a specific word usage in the work of I.P. Kotliarevskyi is considered stylistically normative in modern literary language.

From the point of view of the temporal depth of the literary norm, the word рація has an interesting history. In Eneyida it is a "welcome speech" е.g. «Посли к Латину приступились, Три рази низько поклонились, а стариий рацію сказав». In normative word usage in modern language, it is

${ }^{13}$ Караванський С. Практичний словник синонімів української мови : близько 20000 синонімічних рядів. 4-те вид., опрац. і значно допов. Львів : БаК, 2012. 523 с. 
used like: Ти маєш рацію, Ти не маєш раиіï, and in this case, the normative is associated with a certain spatial identification.

Kotliarevskyi's work Eneyida, significant for the Ukrainian culture, witnessed examples of acclimatization of foreign words, establishing them as expressive conversational means. It is only etymologically that the naming of a "complacent, resolute man" as фертик can be explained due to a comparison with the form and the name of the letter $\phi$ - "hands on hips". For native speakers and connoisseurs of the word, the motivation of this word's position among such synonyms as франт, джигун and жевжик is not clear.

If only the text of Eneyida had been "implanted" in the linguistic culture of modern Ukrainians, then, probably, one more word would be added to the abovementioned synonymic row: "Ласощзохлисти походжали, Всі фертики і паничі, На пальиях ногтики кусали, Розприндившись, як павичі!" In a row of synonyms ферт, чепурун, піжон, жевжик, джигун, прилиза, сноб $\sigma^{14}$, a worthy place would have been given to павич.

For many speakers, lexicographic sources of the 20-30s of the XX century are considered the ideal of the literary norm. Because of a tragic fate of the linguists who worked to establish a literary norm in those years, the spelling standard of 1928-1929 became a kind of symbol of the united Ukrainian language, in fact, a symbolic norm that was to be common written and literary practice of Ukrainians living in mainland Ukraine and in the diaspora.

Some of our contemporaries evaluate the spelling rules recorded in the so-called Skrypnyk's spelling standard, as well as the lexicographical activity of that period, as a golden day of development of the united Ukrainian literary language. In the meantime, it was a process of rapid language formation, in which there were no actually established norms ${ }^{15}$. Each newspaper wrote according to its own rules, the school had no traditions of the Ukrainian language education and upbringing. Linguists also saw the way of development of literary language differently. The dictionaries of that time have records of the following phonetic variants: окромий, окремий; єдиниия, одиниця; пімста, помста; гинджал, кинжал; стирта, скирта; блинець, млинець; ивітень, квітень; икура, икіра; ведмедь, ведмідь; метець, митець, еtc.; word formation variants: видавець, видавник; плавець, плавач, еtс.

${ }^{14}$ Караванський С. Практичний словник синонімів української мови : близько 20000 синонімічних рядів. 4-те вид., опрац. і значно допов. Львів : БаК, 2012. 523 с.

15 Мельник Т.П. Процеси унормування лексики української мови у 20-30pp. XX століття. Автореф. дис. на здобуття наук. ступеня канд. філол. наук. Київ, 2010. 21 с. 
Oleksa Syniavskyi was critical of the tendency to "Ukrainize" the Ukrainian language of that time, denying such a clear tendency: "anything for it not to look like Russian or Polish, just to be 'original', 'own', 'distinctive""16. Quite rightly, the linguist emphasized: "Only where the linguistic nature and linguistic culture converge, at school, finally a single all-Ukrainian literary language will be formed - pure and beautiful" ${ }^{\prime 17}$.

In different historical periods, the processes of rationing and codification were followed by the activation of variants, i.e. periods of relative stability alternated with periods of dynamics, increase in variants' numbers. If the spelling and partially grammatical norm are more or less regularly checked in spelling dictionaries, the symbolization of the lexical norm is more complicated, especially with increasing numbers and intensity of loanwords in the Ukrainian language.

Due to the content of the concept of spatial and temporal depth of the literary norm, criterion of correspondence of the linguistic phenomenon to the fact and to the system of language gets concretization, projecting on the phenomena of historical stylistics of the Ukrainian literary language, diversifying the stylistic remarking of vocabulary in normative dictionaries, typology of stylistic relevance of grammatical phenomena to historical sections of literary language. Various signs of the spatial and temporal depth of the literary norm are revealed in genre and style varieties of the written and oral Ukrainian literary language in a modern synchronous section.

\section{Strong and weak language norm}

Strong, or stable, language norm - regular, traditional implementations of codified language units (phonetic, grammatical, lexical) in written and oral practice. This norm is based on differential features of literary standard, as well as on those characteristics of the national language that distinguish it from related languages. For example, strong language norms are such typical alternation of vowels and consonants of Ukrainian languages such as alternation of $\boldsymbol{o}, \boldsymbol{e}$ in open syllables with $\boldsymbol{i}$ in a closed syllable (yzвiзузвозу - на узвозі, підхід- підходу, сім - семи); alternation of $2, \boldsymbol{\kappa}, \boldsymbol{x}$ with 3 , $\boldsymbol{u}, \boldsymbol{c}$ and $\boldsymbol{ж}, \boldsymbol{4}, \boldsymbol{u}$ (допомога - допомозі - допоміжний; книжка книжиі). Such alternations reveal the specifics of the Ukrainian language against the background of functioning language systems of related languages. A strong norm, though not without exceptions from regular, traditional rules of alternation, stress, word change and word usage, provides for a minimum of such exceptions.

\footnotetext{
${ }^{16}$ Синявський Олекса. Норми української мови. Харків-Київ, 1931. С. 5.

17 Там само. С. 3.
} 
Cases of violation of a strong language norm are typical for speakers who either just begin to learn the Ukrainian language or use it sporadically. In such situations, we record in oral communication violations of stable language norms. For example, those who only get used to the Ukrainian language confuse здібну (instead of здобну) булочку and здібну дівчину, in TV shows we can hear that гості ко́штували вареники (when in fact it should be - гості куштува́ли вареники), some write that спеціалізаиія вимагає нового підхіду (instead of: niдходy). We record rather strange cases of translation. It is difficult to guess, for example, what means the expression східні та відмінні риси. These are, of course, схожі та відмінні риси. Speakers need constant practice in alternation of $\boldsymbol{o}$ with $\boldsymbol{i}$ in a closed syllable, especially in those words that belong to the active vocabulary of contemporaries. Meanwhile, from a high-ranking official we can hear a phrase на Андріївському узвізі, and an error is broadcast to an audience of millions.

The literary norm chooses the path between two laws: the alternation of sounds in closed and open syllables and the analogy to which forms of declension, conjugation, word formation are subordinated. The emergence of variants торговельний - торгівельний we can explain by the law of analogy: the second variant arises by analogy with the noun paradigm торгівля, торгівлі, торгівлю, торгівлею, which naturally keeps $\boldsymbol{i}$ in a closed syllable in all cases forms of the noun. The dictionary codifies the parallel forms згодний and згідний though we have a well-established normative vocabulary in the short form - згоден.

We record the form of the imperative form of the verb заспокоїтися заспокійся (codified forms are заспокойся, заспокойтеся). It is not difficult to establish that the form заспокійся appears as a consequence of the law of analogy from спокій, спокійний, спокійно. If under the influence of the law of analogy or other tendencies the number of exceptions to the rules, which constitute a strong literary norm, is growing, therefore, there is a need to revise the rules of codification of such a linguistic norm.

A weak language norm is an unstable norm that is associated with a regular deviation from the codified rules, with a tendency to alterations in stress, pronunciation, word usage and spelling. In the modern communicative practice, we observe the activation of the Ukrainian language communication in its oral form. At the same time, the normative filter detects weakness, first of all, of the accentuation norm, as well as other structural level norms - lexical and grammatical. Considering the difference between written and oral language, L. Bulakhovskyi gives the opinion of the famous French linguist A. Meillet: "There are many words that we often 
write, but rarely use in a conversation and a lot of those that we pronounce, but do not dare to write down"18.

Observation of modern language practice of people with higher education (teachers, scientists, and writers) indicates a deviation from the codified norms of stressing verbs: ка́жу, ро́блю, но́шу, гово́рю, розпові́ла, вне́сти (пропозицію), ве́сти (дискусію). Characteristically, in everyday communication, as well as on the radio, all prefixal verbs such as донести most often are pronounced with an accented root sound $\boldsymbol{e}-$ приве́сти, дове́сти, наве́сти, підве́сти, as well as приве́зти, підве́зти, дове́зти еtc. However, according to the norm of literary language, they must be pronounced with an accented final syllable for example привести́, довели, підвезли, etc. From philologists we can hear різнови́d instead of a codified normative різно́вид; запитання, чи́тання instead of normative запита́ння, чита́ння. Not only speakers with insufficient language skills training, but philologists as well do not follow the normative pronunciation of the words ви́падок, пересічні громадяни, житло́, фено́мен and incorrectly accent випа́док, пере́січні громадяни, жи́тло, феноме́н. Variants of pronunciation of the word інтелігенція can be considered a sign of carelessness. We hear (see in written) it in different forms: інтелегенція, інтелетенція, інтелигентка, інтилигенція. In general, the pronunciation of foreign words is a weak norm of the literary Ukrainian language; let us consider such common mistakes: гібрід, корєспондєнт, лєкиія, субордінаиія.

The weak norm of stress is the stress of pronoun forms in indirect cases. The general pattern is a change of stress in pronoun forms combined with prepositions, such as мене́ - до ме́не, тебе́ - до те́бе, себе́ - до се́бе. At the same time it is necessary to distinguish the stress of pronouns in the Prepositional case, which retains the stress of all others prepositionless indirect singular forms such as у мені́, на тобі, при собі́. Indistinguishable stress of pronouns in the Prepositional case and accenting them in combination with prepositions in other cases leads sometimes to erroneous conclusions and "unexpected" cultural recommendations. Let us compare the following considerations about the choice of normative stress: "Pronouns in indirect cases accent the last syllable (себé, тебé, мене́, иььоѓ, собí, тобі, мені, иьому), and when they appear in the sentence next to the prepositions, the stress shifts to the first syllable: із се́бе, до те́бе, коло

${ }^{18}$ Булаховський Л.А. Нариси з загального мовознавства. Вибрані твори : У 5 т. Київ, 1980. Т. 1. С. 280. 
ме́не, без иъьо́го, при со́бі, на то́бi, по ме́ні, у иъьо́му"19. In the following examples, dialectal accent is suggested as a norm instead of the literary one like при собі, на тобі, по мені. It is worth to note that such a literary accent in the Ukrainian language is not the influence of the Russian language, but a natural accent in the pronoun system, which is influenced by both the singular form and prepositional compatibility. Pronouns in the Prepositional case with the corresponding prepositions are accented differently than in the Genitive or the Dative cases.

Proper emphasis and literary pronunciation, in particular, should be taught by the theater. Meanwhile, in the theater we see a frequent error: devocalization of sonorous consonant sounds at the end of the syllable or the word, incorrect stress and pronunciation of words, erroneous phraseology. We hear n'ятьдесят (norm is: n'ятдесят), двУХмільйонний or двоХмільйонний (norm is: двомільйонний), піділлєи масла в огонь (norm is: підкинеш хмизу в огонь). The implementation of a certain weak norm should be seen as the effect of the internal language laws development, which are often determined by external conditions, in particular, language culture of society. In the minds of modern speakers, we can see a process of active distancing from the Russian language in those cases that allow the choice of language means. Thus, the phenomenon of hyperism explains common mistakes - cases of replacement of the codified ending of masculine nouns of the second declension, having in the genitive singular ending -а(-я),-- предмета, відмінка, варіанта, атома, об'єкта, документа, паспорта, графіка - by the case forms ending in $-y(-ю)$. Not only do we hear, but we also see in written abovementioned words ending in -y in the genitive singular - предмету, відмінку, варіанту. This ending indicates insufficient semantic motivation to distinguish case endings in masculine nouns of the second declension in the genitive singular. By analogy with this phenomenon, the ending -y extends to the formal phrase до відому (instead of до відома).

We record a weak language norm at the end of the Prepositional case of plural nouns, which conveys the meaning of "distinguishing objects by some signs": по віковим категоріям, по першим фразам (modern norm prefers за віковими категоріями, за першими фразами).

Due to the weak grammatical norm, there is incorrect formation of the Vocative case in the masculine nouns of the second declension (soft group) like місяиь - місяие (instead of місяию), Сергій - Сергіє (instead of Сергію). The mistake is replicated in the children's developmental sound

19 Островський В.І., Островська Г.Ф. А українською кажуть так... Одеса : Астропринт, 2008. С. 29. 
toys (Ukrainian translation made in Dnipro): Мишка та бджілка мандрують в автобусі, щоб побачити місящь: «Привіт, місяще!». It is especially unfortunate that trade for language development of children offers such a Ukrainian literary standard.

The superlative forms of adjectives such as більш цікавіший (instead of иікавіший, більш иікавий), найбільш точніший (instead of найточніший, найбільш точний), більш дохідливіший (instead of найдохідливіший, найбільш дохідливий) are also considered weak grammatical norm. This grammatical mistake occurs as a consequence of contamination of analytical and synthetic forms of degree of comparison in adjectives.

Among the examples of weak lexical norm, there are words that are often used in scientific and colloquial speech. These are paronyms like уява and уявлення, нагода and пригода, зумовлювати аnd обумовлювати, чисельний and численний, as well words whose meanings are delimited by areas of use such as: місткість and ємність. Смність резервуара is sometimes used instead of the phrase місткість резервуара. It is obviously originated from the loanword ємкість without considering the meaning of the physical term ємність. Even in linguistics, the authors in their texts use incorrect phrases ємність парадигми, ємність словникової статті talking about місткість парадигми, статті.

Almost every linguistic and stylistic guide offers recommendations for the correct choice of grammatical forms after verbs дякувати, навчати, навчатися. However, due to the weakness of the grammatical norm we see such mistakes as дякують кого (дякуємо організаторів виставки, дякую Володимира Петровича), instead of кому, навчають, вчать чому (навчити студентів життєвим університетам, у иколі вчать правилам поведінки), instead of чого - життєвих університетів, $y$ школі вчать правил поведінки. Grammatical forms after verbs, recorded in an 11-volume dictionary, sometimes reflect the process of functioning of the weak norm, when one of the options marked as rare goes into the category of non-normative while another one is established as the only norm. For example, the verb сміятися is a weak literary norm as in language practice along with сміятися з кого? з чого? we often observe another variant сміятися над ким? над чим? even though in the dictionary it is marked as rare. In fact, the mark means inequality of the given variants and, accordingly, indicates a weak language norm.

The action of strong and weak language norms is due to complex processes of standardization of literary language, the functioning of its oral and written forms, instability of literary and written tradition, and the interaction of literary variety and territorial dialects of the national language in different historical periods. Then the number of options - lexical, phonetic, grammatical - significantly increases. As a result, the role of 
codification in the practices of linguists, the application of a differentiated approach to cultural advice and stylistic remark in the normative lexicographic sources is growing.

\section{CONCLUSIONS}

Speech culture is the mechanism of formation of normalized, codified literary language. The literary norm is correlated not only with the requirements of the language system, but also with real communicative professional activity, in which the frequency of the use of language tools, the accuracy of the use of terms and the authority of social evaluation of the utterance are important. Along with general literary norm, there are the stylistic norms in various social spheres of modern communications. Professional communication is based on speech culture foundation of the Ukrainian literary language. In addition to a narrow understanding of speech culture as the observance of phonetic, lexical, word-forming, grammatical norms, literary language professional communication involves mastering the speech culture in its broadest sense: it is an assessment of accurate, clear statement, the requirement of a clear, unambiguous opinion. Exemplary language means usage of phraseological richness of the language, linguistic and aesthetic signs, verbal images of classical literature, which became the property of the Ukrainian national culture. The sense of spatial and temporal depth of the literary norm, developing a linguistic taste associated with the aesthetic function of language, with its psycho-emotional influence on the choice of genre of communication is just as important component of speech culture.

\section{SUMMARY}

The terminological meaning of the terms "literary language", "literary language norm" and "speech culture" is considered in the article. An important type of national language - a literary standard with its codified norms (phonetic, lexical, word-forming, grammatical) - has a specific historical meaning. The key concept of literary language is a literary norm that reveals the level of the national-linguistic consciousness, speakers' reflections on the means of speech communication. Codified norms of literary language provide polyfunctionality, polythematic, social prestige of literary language that unites society and ensures the integrity of national culture. The concepts of spatial and temporal depth of the literary norm along with strong and weak norms are described. The emphasis is placed on the communicative, cognitive function of literary language in the formation of professional competence.

Narrow and broad understanding of speech culture are substantiated: the former concerns the evaluative content of units of linguistic usage in their projection on the literary norm, the latter involves the development of a 
sense of language associated with the aesthetic function of language, with its psycho-emotional influence on the choice of genre of communication, use of phraseological richness of language, linguistic and aesthetic signs, verbal images of classical literature, which became the property of the Ukrainian national culture.

\section{REFERENCES}

1. Dubisz Stanislaw. O tym, co sie stalo z jezykiem literackim - raz jeszcze. Stylistyka XXV. 2016. S. 133-143.

2. Бибик С.П. Комунікативний комплекс «усна мова»: сучасна проекція. Життя у слові: зб. наук. праць на пошану академіка В.М. Русанівського. Київ, 2011. С. 276-287.

3. Булаховський Л.А. Виникнення літературних мов. Вибрані праці в 5-ти томах. Т. 1. Київ : Наукова думка, 1975. 496 с.

4. Булаховський Л.А. Нариси з загального мовознавства. Вибрані твори: У 5 т. Київ, 1980. Т. 1. 575 с.

5. Гнатюк Л.П. Мовна свідомість і мовна практика Григорія Сковороди в контексті староукраїнської книжної традиції : Автореф. дис. ... д. філол. наук: 10.02.01 / Інститут філології Київського національного університету імені Тараса Шевченка. Київ, 2011. 35 с.

6. Караванський С. Практичний словник синонімів української мови : близько 20000 синонімічних рядів. 4-те вид., опрац. і значно допов. Львів : БаК, 2012. 523 с.

7. Кононенко В.І. Мова. Культура. Стиль: збірник статей. Київ-Івано- Франківськ, 2002. 460с.

8. Літературна норма і мовна практика: монографія / Срмоленко С.Я. Бибик С.П. Коць Т.А. та ін.; за ред. Срмоленко С.Я. Ніжин : ТОВ «Видавництво «Аспект-Поліграф», 2013. 320 с.

9. Матвіяс I. Варіанти української літературної мови. Київ, 1998. C. $124-150$.

10. Мельник Т.П. Процеси унормування лексики української мови у 20-30 pp. XX століття. Автореф. дис. на здобуття наук. ступеня канд. філол. наук. Київ, 2010. 21 с.

11. Островський В.І., Островська Г.Ф. А українською кажуть так... Одеса : Астропринт, 2008. 400 с.

12. Синявський Олекса. Норми української мови. Харків-Київ, $1931.367 \mathrm{c}$.

13. Старицький М. Передмова до перекладу трагедії «Гамлет» В. Шекспіра. Твори у 8 т. Київ, 1963-1965. Т. 8: Оповідання; Статті; Листи. 1965.

14. Українка Леся. Лист до А. С. Маковей від 28 січня 1894 р. Зібрання творів у 12 т. Київ, 1975-1979. Т. 10. 1978. 
15. Франко I. Зібрання творів у 50-ти томах. Т. 37. Київ, 1982.

16. Януш Я.В. Українські драматурги-класики кінця XIX - початку XX ст. і українська мова. Життя у слові: зб. наук. праць на пошану академіка В.М. Русанівського. Київ, 2011. С. 429-442.

\section{Information about the author:}

Yermolenko S. Ya.,

Doctor of Philological Sciences, Professor, Akademican of the National Academy of Sciences of Ukraine, Head of the Department Stylistics, Language Culture and Sociolinguistics Institute of the Ukrainian Language of the National Academy of Sciences of Ukraine 4, Hrushevskoho str., Kyiv, 01001, Ukraine 